\title{
A turisztikai kereslet fejlesztésének lehetséges irányai egy innovatív városban
}

\author{
Szerző: Albert Tóth Attila1 - Happ Éva²
}

A szabadidős turizmus fejlesztésével kapcsolatos kérdések egyre inkább a figyelem középpontjába kerülnek egy olyan városban, ahol a turizmus hazai viszonylatban már jelentốsnek mondható, de alapvetôen a hivatásturizmus a meghatározó. Győrben a hivatásturizmuson belül elsősorban a külföldi üzleti utazók által generált vendégéjszakák és az ezek kapcsán jelentkezó bevételek jelentôsek, amelyek nagymértékben függnek a városban müködő cégek aktuális beruházásaitól, ezek periodikus hatásaitól. A Győrben üzemeló szállodáknak, vendéglátóhelyeknek, és minden turisztikai szolgáltatónak érdeke és egyben fontos célja is, hogy növelje a szabadidős turizmus részarányát, mellyel szoros összefüggésben csökkenteni tudja függóségét az üzleti turizmus váltakozó intenzitásától. Kutatásunk a győri turizmus egyik fontos fejlesztendô szegmensének, a szabadidōs turizmusnak az értékelésérōl szól, szekunder és primer források elemzésével, kérdőíves és mélyinterjús kutatással.

Kulcsszavak: turisztikai kereslet-kínálat, Győr, városi turizmus.

\section{Bevezetés}

A győri turizmus nagyon sokat fejlődött az elmúlt évtizedekben, amely többek között a vendégéjszakák számának, valamint a városban múködő szálláshelyek minőségének és kapacitásainak növekedésével is jól érzékelhetôvé vált. A jelentős fejlődés elsôsorban a városban letelepedett multinacionális cégek beruházásai által generált hivatásturizmus hatásainak köszönhető. A rendszerváltás után az átalakuló gazdasági és társadalmi viszonyok miatt számos győri üzemet végleg bezártak ugyan, de a városban letelepedő új vállalkozások, elsősorban az 1993-ban létesített Audi Hungária és számos üzleti partnercége, új lendületet adtak a város fejlődésének.

A város földrajzi fekvése és gazdag történelmi múltja, kedvező természeti adottságokat és ember alkotta környezetet teremtett már korábban is a turizmus számára. A három folyó találkozásánál fekvô városban, az épített örökségekben gazdag történelmi belvárosban található a harmadik legtöbb múemlék és múemlék jellegú épület Magyarországon, Budapest és Sopron után. A fejlett iparváros jelleg miatt az üzleti turizmus volt, és jelenleg is ez a meghatározó, de a folyamatosan fejlődő kulturális élet, az oktatási és sportközponttá válás egyre inkább lehetőséget biztosít a szabadidős turizmus számára is. A város turisztikai vállalkozásai folya-

\footnotetext{
egyetemi tanársegéd, Széchenyi István Egyetem, albert.toth.attila@sze.hu ${ }^{2}$ tanszékvezető egyetemi docens, Széchenyi István Egyetem, happ.eva@sze.hu
}

matosan keresik a lehetőségeket a szabadidős turizmus fejlesztésére, részarányának növelésére, a hosszú távú több lábon állás céljából.

\section{Elméleti háttér}

A turizmus szakirodalmának egy része a városi turizmussal, annak sajátosságaival foglalkozik, és a kutatások egyik fókuszában a város, mint turisztikai tér áll. ASHWORTH (1988), ASHWORTH - VOGD (1990), marketing megközelítésben vizsgálták a városok értékesíthetőségét, a turizmus növekedésének lehetőségeit. LAW (1993) szerint a turizmus szempontjából nagyságuk és jelentőségük (fővárosok, nagyvárosok, történelmi városok, kisvárosok) alapján érdemes megkülönböztetni a városokat, hiszen ezek határozzák meg a történelmi városképet, az attrakciókat, a városi konferenciák és kiállítások lehetőségeit (LAW 1993). A szabadidős turizmus kapcsán külön foglalkozik a rövid városlátogató utak jelentőségével, amelyek elsôsorban a repülőtérrel és a jelentôs turisztikai attrakcióval rendelkezó nagyvárosokra jellemzők. Külön fejezetet szentel a kulturális, a sport és a különleges rendezvényeknek, amelyek a legtöbb turista számára a fó motivációt jelenthetik egy város meglátogatásakor, de értékeli a múzeumok, mint turisztikai attrakciók szerepét is a városi turizmuson belül (LAW 1993). PASKALEVASHAPIRA (2007) tanulmánya alátámasztja, hogy egy konkrét város turizmusának elemzésénél érdemes elvégezni a környezeti elemzést, és feltárni a legfontosabb társadalmi, technológiai, gazdasági, környezeti, politikai hatásokat. SPIROU (2011) 
Lektorált tanulmányok

a város turizmusban érintett kerületeit különbözó típusokba sorolja, és ennek megfelelően javasol fejlesztési lehetőségeket, illetve értékeli a mega sportesemények városfejlódésre gyakorolt hatását is. RICHARDS (2011) a kreativitás fontosságával foglalkozik a városi turizmusban, míg szerzôtársával korábban a kulturális események hatásait vizsgálta Rotterdam 2001-es Európai kulturális főváros példáján keresztül (RICHARDS - WILSON 2004). A városi turizmusban a kulturális események száma, minősége, vonzereje, a vendégekre és vendégéjszakákra gyakorolt hatása meghatározó. RICHARDS (2014) szerint a kreativitásnak nagy szerepe van új turisztikai termékek fejlesztésében, a meglévô termékek úiraélesztésében, a városok, a konkrét helyszínek atmoszférájának és a városmárkának a kialakításában. VALLS et al. (2014) Európa legjelentósebb városainak turizmusát vizsgálva megállapították, hogy a városokra jellemzố szabadidős turizmus formái, a rövid városlátogatások, a rövidebb vagy hosszabb vakációk, eltérést mutatnak a nemzetközi és a hazai turizmusban. Értékelték, és összefüggéseket kerestek a városok adottságai és a városokat választó turisták attitúdjei, valamint a városok által alkalmazható marketing kommunikáció között. A városi turizmus versenyképességét CIBINSKIENEA - SNIESKIENEB (2015) a külsó és a belsô környezet fontos faktorainak, a turisztikai erőforrásoknak és az infrastrukturális adottságok által meghatározott elemeknek tulajdonítják.

A városi turisztikai termékek fejlesztésének és a városban lakó állandó lakosok jólétének kapcsolatát kutatták TOKARCHUK et al. (2016) német városok példáján. Kimutatták, hogy számos turisztikai fejlesztés pozitív hatással van a közösségi életre, amely elónyös a helyi lakosok számára, és jó hatással van az életminôségre is. MIKULIC et al. (2016) az Európai fóvárosok márkaerejének és a turizmus intenzitásának kapcsolatát vizsgálták. Elemzésükben kimutatták a kettő közötti erős, szignifikáns kapcsolatot.

A magyar tudományos és turisztikai szakirodalom is foglalkozik a legjelentósebb városok elemzésével, melyek közül néhány tanulmány Gyôr turizmusát is elemezte. MICHALKÓ (1999) könyvében részletesen feldolgozza a turizmus városfejlesztési vonatkozásait, a városi turizmus társadalmi hatásait. A városok olyan szabadidôs terek, ahol a turisták nevezetességeket keresnek fel, kulturális rendezvényeken vesznek részt, és turisztikai szolgáltatásokat vesznek igénybe. Marketing szemléletú megközelítésben a város egy olyan szabadidős termék, amelyet a turisták élmények szerzésére használnak (MICHALKÓ 1999). ALBERT TÓTH (2016) értékeli Győr város turizmusát, szállodaiparát, a városban kialakult egyedi szálláshelyi struk- túrát. A nyolcvanas években még egy nagy szálloda, a Rába, jelentette a győri szállodaipari kínálat alapját és a szállodai kapacitás nagyobb részét, de a kilencvenes években, majd később, a 2007-től felgyorsult szállodaipari fejlesztéseknek köszönhetően mára már egy sokszínú, színvonalas szállodai struktúra alakult ki a városban. Nagyon hiányzik viszont Győrben egy jó minóségú és nagy kapacitású gyógy-, vagy wellness szálloda, amelynek kiváló helyet biztosíthatna a Rába Quelle Gyógy-, Termál és Élményfürdő. A nyolcvanas évek közepén még tervek is készültek egy ilyen jellegú szállodára az akkori termálfürdő mellett, de azóta sem valósultak meg sem ezek, sem más késóbbi gyógyvagy wellness szállodai beruházások. A gyógyvagy wellness szálloda az eddigihez képest egy új vendégkör megjelenését jelenthetné a városban, és növelhetné mind a tartózkodási időt, mind a bevételeket (ALBERT TÓTH 2016).

Győr ipari város jellege átalakulóban van, és egyre hangsúlyosabban van jelen a turizmus, amelyet a város állandó lakossága is jól érzékel. Egy 2015-ös kérdőives felmérésben, amelyben 560 fó győri lakos vett részt, a válaszadók 79\%-os arányban úgy ítélték meg, hogy fejlődött a város idegenforgalma (TÓTHNÉ 2015). Az utóbbi évek infrastrukturális intézményi fejlesztései (látogatóközpont, szállodák) és a már nem csak a városi lakosság számára szervezett kulturális rendezvények, turisztikai vonzerővel rendelkezó programok jelentôs számú turistát csábítanak a városba. Győr egyre nagyobb hangsúlyt fektet a városmarketingre is, hogy a városban élók, a befektetők és a turisták számára is vonzó hely legyen (JAKAB - HAPP 2017). RECHNITZER (2016) a területi tóke szerepét vizsgálja Győr példáján, és a városfejlődés kapcsán foglalkozik a város turizmusával is. Fontos innovációs tényezônek tartja a városban az 1960-70-es években megjelenó, majd a rendszerváltás után megerôsödő bevásárló turizmust, annak kereskedelemélénkítő hatását. Megállapítja, hogy a város szálláshelyeinek többsége a folyamatosan erôsödő gazdaságot, a megjelenô új vállalkozások beruházásait szolgálta, és a kilencvenes évektől jelentôs üzleti turizmus alakult ki. Ezáltal egyre nagyobb igény támadt a magasabb kategóriájú szállodákra, míg a panziók, egyszerúbb szálláshelyek iránti kereslet mérséklődött (RECHNITZER 2016).

\section{Módszertan}

A város turisztikai szolgáltatói részéról felmerült az igény, hogy a győri szabadidős turizmus erősítése céljából készüljön egy olyan felmérés, amely nem a város turizmusának általános értékelésérôl szól, hanem elsősorban a szabadidős turizmusra 
fókuszál, mivel ilyen jellegû, nagymintás turizmuskutatás korábban még nem készült a városban. A kutatás célja tehát az volt, hogy megvizsgáljuk, Győr városának milyen lehetőségei vannak a szabadidős turizmusban. Győr városára - amelynek gazdasága elsósorban az iparra épül - az üzleti turizmus a jellemző. Kutatásunkban vizsgáljuk, hogy azok a turisták, akik már jártak Győrben, milyen motivációval rendelkeznek, milyen szolgáltatásokat vennének igénybe.

A kutatási célok alapján az alábbi kutatási kérdést fogalmaztuk meg: Az üzleti turizmus mellett melyek azok a szabadidős turisztikai termékek, amelyekre potenciális kereslet jelentkezik a Győr városa iránt érdeklődő turisták részéről?

A kutatás adatbázisát három különböző forrásból szerzett adathalmaz képezte. Az elemzés az elméleti háttér bemutatása után, a fontosabb szekunder adatok segítségével, a város jelenlegi turisztikai helyzetét méri fel. A szekunder adatokat a Központi Statisztikai Hivatal, a város Önkormányzata, illetve a turisztikai szolgáltatók biztosították. A primer adatok a potenciális turisták körében kitöltött online kérdőívből és mélyinterjúk készítéséból származnak. A primer kutatást 2017 tavaszán, a Széchenyi István Egyetem turizmus-vendéglátás szakos, nappali tagozatos hallgatóinak közremúködésével, és a város turisztikai szolgáltatóinak támogatásával készítettük. Az egységesített, előzetesen tesztelt, strukturált online kérdőívet összesen 1272 fő töltötte ki, olyanok, akik már jártak turisztikai céllal a városban, vagy tervezik, hogy a közeljövőben meglátogatják. A kérdőív feldolgozása és kiértékelése SPSS program használatával történt. A kérdőíves kutatás eredményeit kiegészítve 10 mélyinterjút készítettünk szállodavezetőkkel, az önkormányzati referenssel és a Tourinform iroda vezetőjével.

\section{A kutatás eredményei}

\subsection{GYÓR TURIZMUSÁNAK FŐBB JELLEMZÖI}

Győr turizmusának alapját a hivatásturizmus adja, ezen belül is a győri cégekhez, intézményekhez érkező üzletemberek utazásai dominálnak, a szálláshelyeken eltöltött vendégéjszakák többsége is hozzájuk kötődik. Az elmúlt évtizedben, de korábban is megfigyelhetô volt, hogy a városban múködő cégek, főként az Audi, beruházásai és a bevásárlóközpontok építése generálják az üzleti turizmus nagyobb részét. Amikor nincs folyamatban valamilyen jelentős céges beruházás, akkor a stagnálás a jellemző, és ezt nagyon megérzik a szállodák, éttermek, turisztikai szolgáltatók, illetve az elmaradt forgalmi és adóbevételek miatt a város is. A tu- rizmus mértékének beruházásoktól való függését csökkenteni kellene a turisztikai kínálat fejlesztésével, a szabadidős turizmus részarányának növelésével. Az Önkormányzat nem végez statisztikai adatfelvételt a városba érkező turisták motivációjáról, de a mélyinterjúk alapján elmondható, hogy a szállodai szolgáltatást igénybevevôknek körülbelül 10 \%-a érkezik csak szabadidős célból a városba.

A konferenciaturizmus is jelen van a városban, elsősorban az orvosi-egészségügyi jellegú konferenciák jellemzőek, a regionális szerepet is betöltő Petz Aladár Megyei Oktató Kórház szerepének és a kórházi infrastruktúrának köszönhetően. Ezen kíviul a győri és az országos vállalatok is gyakran tartanak a városban gazdasági, múszaki témájú tréningeket, továbbképzéseket, konferenciákat. Ugyanakkor a város nem rendelkezik igazi konferencia központtal, a Győr-Moson-Sopron Megyei Kereskedelmi és Iparkamara épülete, a Széchenyi István Egyetem, a győri Nemzeti Színház és a szállodák különtermei alkalmasak elsősorban az ilyen jellegú rendezvények, konferenciák lebonyolítására.

A kulturális turizmus Győr legfontosabb, szabadidős kategóriába sorolható, turisztikai terméke. A városban múködik a világhírú Győri Balett társulata, amelyet még 1979-ben alapítottak a Magyar Állami Balettintézet akkori végzősei, Markó Iván vezetésével. Győr valódi fesztiválvárossá vált az elmúlt két évtizedben, egész évben folyamatosan egymást érik a múvészeti, zenei, tánc, és egyéb fesztiválok. A Nemzetközi Ütős Fesztivál, a Nemzetközi Táncfesztivál, a Magyar Hagyományok Fesztiválja és az Öt Templom Fesztivál emelhetô ki a sok más kulturális rendezvény közül (HANCZ 2017). A város 2007-es turizmusfejlesztési stratégiája még úgy értékelte a korábbi fesztiválok szerepét, hogy a rendezvények a régión kívüli területekről nem képesek turistákat vonzani a városba (BUDAI - BARTA 2007). Egy 2009-es saját kutatás szerint, körülbelül 2-3 \% közé tehetô azoknak a szállodai vendégéjszakáknak a részaránya, amelyek közvetlenül valamilyen kulturális fesztiválhoz, rendezvényhez köthetôk Győrben (ALBERT TÓTH 2009). Azóta változott a helyzet, több rendszeressé váló fesztiválnak már sikerült országos hírnévre szert tennie, amelyek már valóban vendégéjszakákat is jelentenek a város szálláshelyein. Ilyen a Gyôrkốcfesztivál, amely Győr városára és a gyerekekre utaló humoros és nagyon találó szóösszetétel. Az elnevezés és a fesztivál is sikeres lett az elmúlt néhány évben. Egy nyári hétvégére a gyerekeké a győri belváros, rengeteg programmal, músorral, vetélkedőkkel. A gyerekeket természetesen elkísérik a szüleik is, így a város szálláshelyei ilyenkor megtelnek az ország különböző pontjáról érkező 
Lektorált tanulmányok

belföldi vendégekkel. A Győrkốcfesztivált 2008-ban rendezte meg először a város, és már a harmadik évben szinte teltházasak lettek a város szálláshelyei azon a hétvégén, így a rendezvény nagyon hamar bizonyította, hogy igazi turisztikai vonzereje van és jelentős bevételeket képes generálni.

A sokszínú és rendkívül gazdag kulturális élet, illetve a kiváló intézményei miatt Győr pályázik a 2023-as Európa Kulturális Fốvárosa címre, és biztos, hogy a cím elnyerése esetén egyedülállóan magas színvonalú programsorozatot képes majd lebonyolítani³. A megyében létrejött egy széleskörú összefogás, amely alapján Győr nem egyedül, hanem más városokkal és partnerekkel együtt pályázik. Sopron, Fertőd, Pannonhalma, valamint a Fertó-Hanság Nemzeti Park kulturális, vallási, természeti adottságai és turisztikai vonzerói erősíthetik a pályázat értékét (SUDÁR 2017).

A pályázat fontos elôzménye, hogy Győr már korábban, 2010-ben, elnyerte a Kultúra Magyar Városa, a Legsportosabb Város és az Idősbarát Önkormányzat címeket, illetve az Év Tourinform irodája cím is a városé lett, igazolva a város turisztikai szakembereinek lelkes munkáját, és a város vezetésének a turizmus jelentőségét felismerô támogatását. „Győrben az Egészség, a Kultúra és az Innováció találkozik, ez garantálja mindazt, amit a város szlogenje is hirdet: A jövő Győrben épül!" (GYŐR-MOSON-SOPRON MEGYEI ÖNKORMÁNYZAT 2016:8).

A városban a vallási turizmus is egyre inkább fontossá válik, köszönhetően a város bazilikájában található jelentôs kegytárgyaknak, a Szent László hermának, az Írországból származó könnyezô Szúz Mária képnek, és boldog Apor Vilmos síremlékének. A hozzájuk köthető események több ezer vendéget vonzanak a városba minden évben. Győrtől nem messze, mintegy $23 \mathrm{~km}$ távolságra található Pannonhalma, amelynek bencés monostora az UNESCO világörökségi listán található. A két város közelsége kölcsönösen erősíti mindkét város potenciális turisztikai vonzerejét, nem csak a vallási célból utazók esetében.

A sportélet országos szinten is kiemelkedő, de a város számos nemzetközi sporteseménynek is helyt adott már. Győr világviszonylatban is a kézilabda egyik fellegvára, a városban múködik a már háromszoros BL győztes Audi ETO KC nói kézilabda csapata. A folyók adta adottságoknak köszönhetóen már többször rendeztek a városban maratoni kajak-kenu világbajnokságot, és 2017 nyarán itt rendezték az Európai Ifjúsági Olimpiai Fesztivált is (EYOF). A nagyszabású sportesemény miatt több új sportlétesítmény és szálláshely épült,

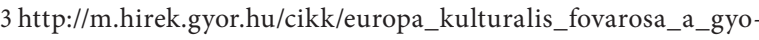
riek_bevonasaval_keszul_a_varos_2023_ra.html a régebbieket pedig felújították, így tovább emelkedett a város sporttal kapcsolatos infrastruktúrájának színvonala és kapacitása.

A nagyvárosokra jellemző, néhány napos city break jellegú városlátogatások szerény mértékben ugyan, de növekvő tendenciát mutatnak. Elsősorban hétvégéken és ünnepnapokon érkeznek a fóleg belföldi turisták a város és a szállodák által kialakított, egységesített városlátogató csomagajánlatoknak köszönhetóen. A különböző csomagok más és más célcsoportnak szólnak, a beépített szolgáltatásoktól, programlehetőségektól függően. Van olyan csomagajánlat, amelyikben a fó tartalmi elem egy fürdóbelépő, egy színház- vagy koncertjegy, állatkert látogatás, városnézés idegenvezetővel vagy lovas sétakocsikázással, esetleg hajózással a város folyóin. A bevásárlóturizmus az osztrák és a szlovák határ közelsége, illetve a színvonalas gyơri bevásárlóközpontok miatt szintén a hétvégén jellemző, bár erős hullámzást mutat, elsősorban az Euro/Forint árfolyam ingadozásának függvényében.

Az aktív turizmus a nyári fôszezonban szintén jelen van a városban. Győr az Eurovelo 6-os európai kerékpárút hálózat részeként, a Bécsból Budapestre kerékpározó turisták számára jelent egyéjszakás városi tartózkodást a külföldi vendégeknek. A vízi turizmus lehetóségei sajnos nincsenek elég jól kiépítve és kihasználva a városban. A Szigetköz, amely erre alkalmas, nagyon közel van. Győr egyik városrésze földrajzilag már a Szigetköz része, és a város folyószakaszai is használhatóak lennének kenus vízitúrák kiinduló vagy érkező állomásaként.

\subsection{A KERESLET-KÍNÁLATI VISZONYOK ALAKULÁSA}

Győrben 2016-ban 58 kereskedelmi szálláshely múködött, ebből 34 volt az üzemelő szállodák és 18 a panziók száma. A városban összesen 1557 kiadható szobával rendelkeztek a kereskedelmi szálláshelyek, amelynek 74\%-át a szállodai kapacitás tette ki, 1152 szobával. A szállodák mintegy harmada rendelkezik Hotelstars Union minósítéssel, ami a város szállodai szobakapacitásának mintegy felét jelenti. A 3*-os kategóriában 373 szoba, míg a 4*os kategóriában 169 szoba található (KSH 2016). A nem minősített, kategória nélküli szállodák kapacitásának többsége, a győri szállodai gyakorlat tapasztalatai alapján, a korábbi osztályba sorolás (45/1998. IKIM rendelet) szerinti háromcsillagos minőségi szinten múködik, kisebb része a kétcsillagos szintnek megfelelóen.

A győri szállodák, szálláshelyek kapacitásai folyamatosan változtak az elmúlt évtizedben, négy jelentős új szálloda lépett be a győri szállodai piacra. 2007-ben két szálloda (Famulus, Ibis), 2012-ben a Győri 
Nemzetközi Ipari Parkban a WHB, majd 2012-ben a 'stadionpanorámás' ETO Park Hotel. Ezek a szállodák jelentősen hozzájárultak ahhoz, hogy a városban végrehajtott beruházások lebonyolítására érkezó vendégeket magas színvonalon lehetett elszállásolni.

A győri vendégek és vendégéjszakák száma a gazdasági válság hatására a 2009-es évben egy kicsit visszaesett a korábbiakhoz képest, de már a következő évtôl kezdve jelentős növekedésnek indult (1. ábra). A 2012-es évben az Audi gyárban megindult új gyáregység építésének vendégforgalomra gyakorolt hatásai évrôl évre érezhetők voltak. Az Audi mellett más üzemek is beruházásokat valósítottak meg, így a 2016. évi vendégforgalmi adatok még a korábbi eredményeket is túlszárnyalták (KSH 2008-2016). A szállodák szolgáltatásai is elsősorban az egyéni üzleti utazók igényeihez alkalmazkodnak, kevésbé jellemzőek a hosszabb ideig tartózkodó vendégek, akik sokféle és színvonalas szabadidős szolgáltatást, programokat igényelnének a szállodán belül.

Vendégéjszakák száma a kereskedelmi szálláshelyeken Győrben 2008-2016 között

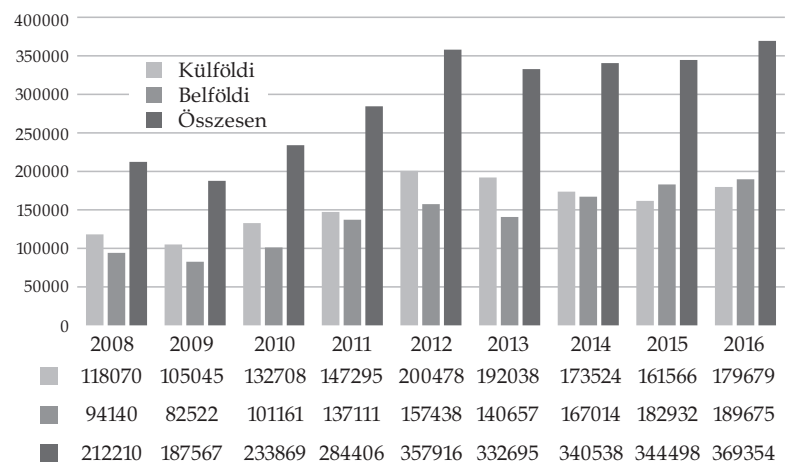

Forrás: saját szerkesztés a KSH adatai alapján

A 'Magyarország leglátogatottabb települései' országos listán 2016-ban Gyór a 11. helyezést érte el a kereskedelmi szálláshelyeken regisztrált vendégéjszakák száma alapján, nagyon kevéssel lemaradva a legjobb tíztől. A külföldi vendégéjszakák alapján viszont már sikerült az első tízbe bekerülni, a 8 . helyezett Győrt csak Budapest, Hévíz, Bük, Hajdúszoboszló, Sárvár, Balatonfüred és Siófok tudta megelőzni (MTÜ 2017). Az átlagos tartózkodási idó Magyarországon (2,5 éj/fó), ami alatta marad az európai átlagnak (HAPP - ÉKES 2014), de a győri szálláshelyeken még alacsonyabb ez az érték, itt az átlagos tartózkodási idô 2,2 vendégéj/fó körül mozog (KSH 2008-2016). A belföldi vendégek száma még mindegyik vizsgált évben kevesebb volt, mint a külföldieké, de a belföldi vendégéjszakák száma már 2015-ben és 2016-ban is meghaladta a külföldiekét, ami biztató jel a belföldi szabadidős turizmus fejlődése szempontjából (KSH 2008-2016).

Győrben a Széchenyi Pihenőkártyát (SZÉP) elfogadó kereskedelmi szálláshelyek száma 44 volt 2016-ban, ezek összesen 126 millió forint forgalmat generáltak. A SZÉP kártya bevezetése óta növekedett az elfogadóhelyek száma és a kártya forgalma is: 2012-ben 34 szálláshely 61 millió forint, 2013-ban 38 elfogadóhely 80 millió forint, 2014-ben 39 szálláshely 109 millió forint, 2015-ben 42 egység 98 millió forint forgalmat realizált. A SZÉP kártya forgalom és a belföldi szobaár bevétel arányai viszont nem sokat változtak. A vizsgált öt évben $8 \%$ és 12\% között volt a SZÉP kártyával történó fizetés részaránya a győri szálláshelyeken, ami az országos átlag alatt van. Ez arra utal, hogy a SZÉP kártya forgalmának és részarányának növelésével adott lenne a lehetóség a belföldi szabadidős turizmus mértékének emelésére, de ehhez olyan programok, szolgáltatások és nem utolsó sorban marketing kommunikáció kell, amelyek segítségével jobban megszólíthatóak, elérhetőek a SZÉP kártyával rendelkező potenciális turisták (KSH 2012-2016). A győri kereskedelmi szálláshelyek összes szobaár bevétele megduplázódott a 2008 és 2016 közötti időszakban. 2016-ban már meghaladta a 3 milliárd forintot, melynek $61 \%$-a volt a külföldi vendégekhez köthetô érték (KSH 2008-2016).

A legfontosabb győri mutatószámokat a másik, hasonló nagyságú és jelentőségú magyarországi autóipari centrummal, Kecskeméttel öszszehasonlítva a következők állapíthatók meg. A szálláshelyek kapacitása Győrben csaknem kétszer akkora volt 2008-ban és 2016-ban is, mint Kecskeméten, de a növekedés mértéke Kecskeméten (55\%) gyorsabb volt, mint Győrben (34\%). Kecskeméten jelentős szállodai kapacitás bővülés történt 2011 és 2013 között, amely a 2012 márciusi Mercedes gyár megnyitásának köszönhető. A vendégéjszakák száma Győrben több mint kétszerese a Kecskemétinek a vizsgált időszak mindegyik évében, kivéve a 2011-es évet, amikor a Mercedes gyár még beruházási fázisban volt. Hasonlóképpen, ahogy annak idején Győrben is történt, a gyár utána átkerült a termelési, üzemelési fázisba, így a vendégéjszakák száma először átmeneti visszaesést, majd stagnálást, később némi emelkedést mutatott. A szálláshely bevételek 2011-ben a korábbiakhoz képest több mint a kétszeresére növekedtek Kecskeméten, majd utána követték a vendégéjszakáknál tapasztalt viszszaesést, stagnálást, kismértékú emelkedést. A turizmus mértékének beruházás függése tehát nemcsak Győrben, hanem Kecskeméten is jól ki- 
Lektorált tanulmányok

mutatható! Kecskeméten viszont sokkal gyorsabb ütemben növekedett a SZÉP kártya által generált belföldi szobaár bevétel 2012 és 2016 között. Míg Győrben közel a duplájára, addig Kecskeméten csaknem a négyszeresére, 97,3 milliárd forintra emelkedett, ami a megépült új szállodák szabadidős turizmusra gyakorolt kedvező hatását mutatja (KSH 2012-2016).

\subsection{A KÉRDŐÍVES KUTATÁS EREDMÉNYEI}

A primer kutatás részeként magyar nyelvú online kérdőíves felmérést végeztünk 2017. március 5. és április 11. között, amelyet 1272 fó töltött ki. A válaszadók között volt olyan, aki győri lakos, és olyan, aki nem járt és nem is szeretne Győrbe látogatni, őket kiszûrrtük a mintából, mivel a kutatás fó célja a városba látogató turisták fogyasztói magatartásának vizsgálata volt. A fennmaradó minta 1055 fős, akik közül voltak, akik már jártak Győrben és olyanok is, akik csak tervezik. Jelen kutatás adatbázisát tovább szúkítettük azokra, akik már jártak Győrben, így a szû́rt adatbázison az érvényes esetszám 841 fó, akik közül 79-en külföldi állampolgárok, a többi válaszadó magyar. A kérdőív feldolgozására SPSS program segítségével került sor.

Az életkor esetében az látható, hogy a 20-29 éves korosztály felülreprezentált azok között, akik már jártak turistaként Győrben (1. táblázat). A függóként vizsgált változók teljes konzisztenciája elfogadható, Cronbach-alfa a vizsgált mintára 0,628.

\section{A minta eloszlása szocio-demográfiai szempontok szerint}

\begin{tabular}{|l|l|l|}
\hline Nem & Férfi & $32,5 \%$ \\
\hline & Nó & $67,5 \%$ \\
\hline Életkor & $15-19$ & $6,4 \%$ \\
\hline & $20-29$ & $44,2 \%$ \\
\hline & $30-39$ & $15,6 \%$ \\
\hline & $40-49$ & $14,7 \%$ \\
\hline & $50-59$ & $14,3 \%$ \\
\hline Családi állapot & $60+$ & $4,8 \%$ \\
\hline & Egyedülálló & $26,3 \%$ \\
\hline & Házas & $67,4 \%$ \\
\hline Iskolai végzettség & Elvált & $3,2 \%$ \\
\hline & Özvegy & $3,1 \%$ \\
\hline & legfeljebb 8 általános & $4,0 \%$ \\
\hline & szakmunkásképzó & $10,6 \%$ \\
\hline & érettségi & $41,3 \%$ \\
\hline & felsófokú szakképzés & $14,5 \%$ \\
\hline & fóiskola/egyetem & $29,6 \%$ \\
\hline & &
\end{tabular}

Forrás: saját szerkesztés
Elsóként azt vizsgáltuk, hogy milyen céllal keresték fel a turisták a várost. A látogatás céljánál a válaszadók több válaszlehetőséget is megjelölhettek. A többválasztós kérdéseket elemenként dichotómmá alakítva a teljes 841 fős mintában mutatkozó megoszlás az összes cél esetében (az igennel válaszolók százalékos aránya alapján) a 2. ábrán látható.

A várost felkeresố turisták motivációja (\%)

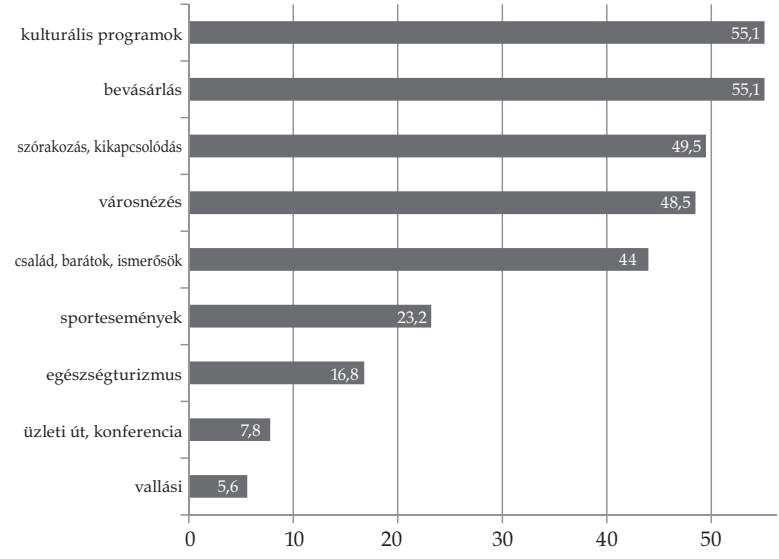

Forrás: saját szerkesztés

Az elemzés alapján megállapítható, hogy a válaszadók szerint Győrben a kulturális programok megtekintése a leginkább vonzó program, a bevásárlás mellett legszívesebben emiatt keresik fel a várost. Nagyobb mértékú említésszámot a szórakozás, kikapcsolódás, a városnézés és a VFR (család, barátok, ismerősök meglátogatása) kapott. Az egy válaszadóra jutó kiválasztott célok átlagos száma 2,59, a legtöbb válaszadó $2(27,7 \%)$ vagy $3(24,7 \%)$ motivációt jelölt meg a kérdőívben. Azt vizsgálva, hogy milyen összefüggések vannak a különböző célok kiválasztása között, a következő eredményeket láthatjuk. A 2. táblázat mátrixa azt mutatja, hogy az adott tevékenységet említők milyen arányban jelölték meg a többi motivációt.

A 2. táblázatban jól látható, hogy a leggyakoribb motivációként megjelent kulturális programok mellé a válaszadók a többi motivációt is szívesen választják. A bevásárlás esetén ez már nem ilyen egyértelmú, hiszen ennél a motivációnál azt látjuk, hogy a vallási turizmushoz hasonlóan ezt kevesebben jelölték meg célként. A vallási turizmus céljából érkező látogatók nem kötik öszsze más tevékenységgel az utazásukat. Ugyanezt tapasztalhatjuk a sportesemények látogatására vonatkozóan az egészségturizmus és üzleti célból érkező vendégek esetén is. Ezek a motivációk 
Motivációk összefüggése (\%)

\begin{tabular}{|c|c|c|c|c|c|c|c|c|c|}
\hline & $\begin{array}{c}\text { család, } \\
\text { barátok, } \\
\text { ismerö- } \\
\text { sök }\end{array}$ & $\begin{array}{c}\text { kulturá- } \\
\text { lis prog- } \\
\text { ramok }\end{array}$ & $\begin{array}{l}\text { város- } \\
\text { nézés }\end{array}$ & $\begin{array}{c}\text { sporte- } \\
\text { semé- } \\
\text { nyek }\end{array}$ & vallási & $\begin{array}{l}\text { bevá- } \\
\text { sárlás }\end{array}$ & $\begin{array}{l}\text { egész- } \\
\text { ségtu- } \\
\text { rizmus }\end{array}$ & $\begin{array}{c}\text { szóra- } \\
\text { kozás, } \\
\text { kikap- } \\
\text { csoló- } \\
\text { dás }\end{array}$ & $\begin{array}{c}\text { üzleti } \\
\text { út, } \\
\text { konfe- } \\
\text { rencia }\end{array}$ \\
\hline $\begin{array}{c}\text { család, barátok, } \\
\text { ismerösök }\end{array}$ & & 59,5 & 49,5 & 24,6 & 7,3 & 63,2 & 18,4 & 53,0 & 10,5 \\
\hline kulturális programok & 47,5 & & 53,1 & 27,2 & 6,3 & 62,0 & 20,3 & 51,4 & 9,3 \\
\hline városnézés & 44,9 & 60,3 & & 23,3 & 6,6 & 53,9 & 18,4 & 52,5 & 9,3 \\
\hline sportesemények & 46,7 & 64,6 & 48,7 & & 5,1 & 64,6 & 21,5 & 55,4 & 9,2 \\
\hline vallási & 57,4 & 61,7 & 57,4 & 21,3 & & 38,3 & 27,7 & 31,9 & 10,6 \\
\hline bevásárlás & 50,5 & 62,0 & 47,5 & 27,2 & 3,9 & & 21,0 & 54,6 & 9,3 \\
\hline egészségturizmus & 48,2 & 66,7 & 53,2 & 29,8 & 9,2 & 68,8 & & 70,2 & 11,3 \\
\hline $\begin{array}{l}\text { szórakozás, } \\
\text { kikapcsolódás }\end{array}$ & 47,1 & 57,2 & 51,4 & 26,0 & 3,6 & 60,8 & 23,8 & & 9,4 \\
\hline üzleti út, konferencia & 59,1 & 65,2 & 57,6 & 27,3 & 7,6 & 65,2 & 24,2 & 59,1 & \\
\hline
\end{tabular}

Forrás: saját szerkesztés

önálló tevékenységként jelennek meg a turisták választásaiban.

Vizsgáltuk azt is, milyen összefüggések vannak a különböző célok választása között, és azt az eredményt kaptuk, hogy a legnagyobb arányban jelölt kulturális programok köré csoportosul a többi tevékenység jelentős része. A bevásárlás, mint a látogatás célja, a legtöbb célhoz kapcsolódóan kiegészító programként jelenik meg. Negatív irányú szignifikáns összefüggésekkel csak a vallási célból történő látogatás esetében találkozhatunk, a vallási turizmus motivációja a bevásárlás és a szórakozás céljával nem kapcsolódik. A városnézés a leginkább semleges, a kulturális programokon kívül nem igazán kapcsolódik öszsze semmivel.

A motivációkat szocio-demográfiai tényezőkön keresztül is vizsgáltuk. Elemeztük, hogy a kérdő́ivben megválaszolt változók, mint a kor, nem, családi állapot, végzettség, hogyan befolyásolják a turisztikai célokat. A négy szocio-demográfiai változó megoszlásait külön-külön ábrázoltuk, célonként elemezve a diagramokon. $\mathrm{Az}$ elemzéseknél végeztünk függetlenségvizsgálatot, értékelve a hozzá tartozó szignifikancia értéket, illetve a kontingencia-együtthatóval vizsgáltuk a kapcsolat erősségét. A szignifikáns eltéréseket minden változónál kiemeltük az elemzésben. A próbák az adott célt említók és nem említők eloszlásai közötti eltérést vizsgálták. A kontingencia-együttható nagyságát zárójelben jeleztük.

\section{Nemek szerinti megoszlás az egyes motivációk esetén (\%)}

3. ábra

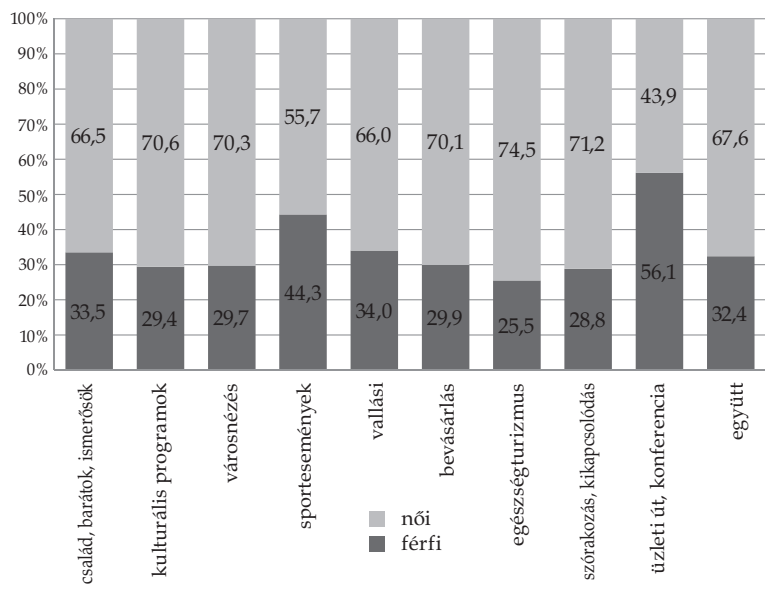

Forrás: saját szerkesztés 
Lektorált tanulmányok

A nemek szerinti vizsgálatnál jól látható, hogy az üzleti turizmusban nagyobb arányban vesznek részt férfiak, mint nôk (3. ábra). Szignifikáns eltérés mutatkozott az említők és a nem említók között a kulturális programok $(0,071)$, a sportesemények $(0,139)$, a szórakozás $(0,075)$ és az üzleti út $(0,146)$ esetén. Zárójelben a kontingencia-együttható nagysága látható, amely a kapcsolat erősségét mutatja. Ez a vizsgálat is erős eltérést mutat az üzleti utak esetén. Így az elemzés alapján elmondható, hogy a nem, mint szocio-demográfiai változó befolyásolhatja a turizmusban való részvétel motivációját.

A kor, mint szocio-demográfiai változó motivációnkénti megoszlása a 4. ábrán látható. A minta eloszlásának vizsgálatánál az életkor esetében az látható, hogy a 20-29 éves korosztály felülreprezentált azok között, akik már jártak turistaként Győrben.

\section{Kor szerinti megoszlás az egyes motivációk esetén (\%)}

4. ábra

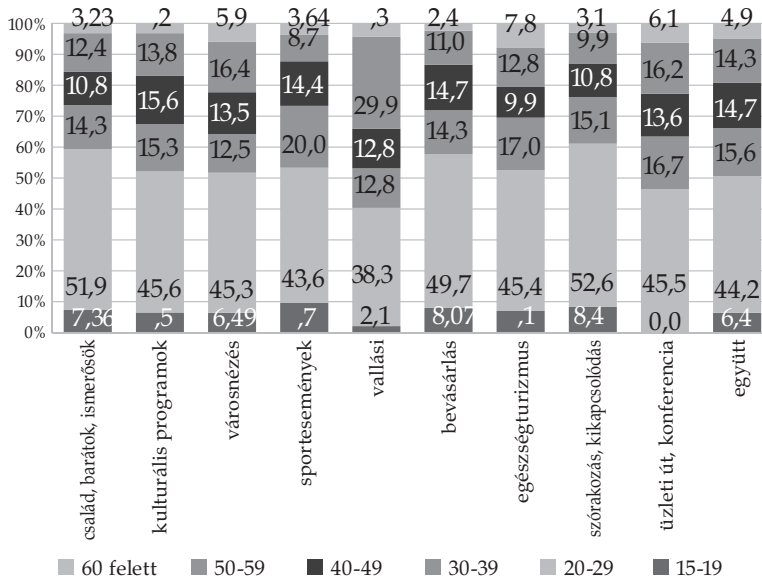

Forrás: saját szerkesztés

A vizsgálat alapján elmondható, hogy az életkor olyan tényezőnek tekinthetó, amely jelentősen befolyásolja adott célok választását. Az ismerősök látogatása, a bevásárlás és a szórakozás fiatalosnak tekinthetô, míg a vallási turizmus ellenkező képet mutat. A vallási turizmus esetében az idősebb korosztály tekinthető elsődleges célcsoportnak. Szignifikáns eltérés mutatkozott az említők és a nem említők között a VFR $(0,159)$, sport $(0,127)$, bevásárlás $(0,191)$, szórakozás $(0,220)$ esetén. Zárójelben a kontingencia-együttható nagysága látható, amely a kapcsolat erósségét mutatja.

A családi állapot, mint szocio-demográfiai változó elemzésének eredményei az 5. ábrán láthatóak.

\section{Családi állapot szerinti megoszlás az egyes} motivációk esetén (\%)

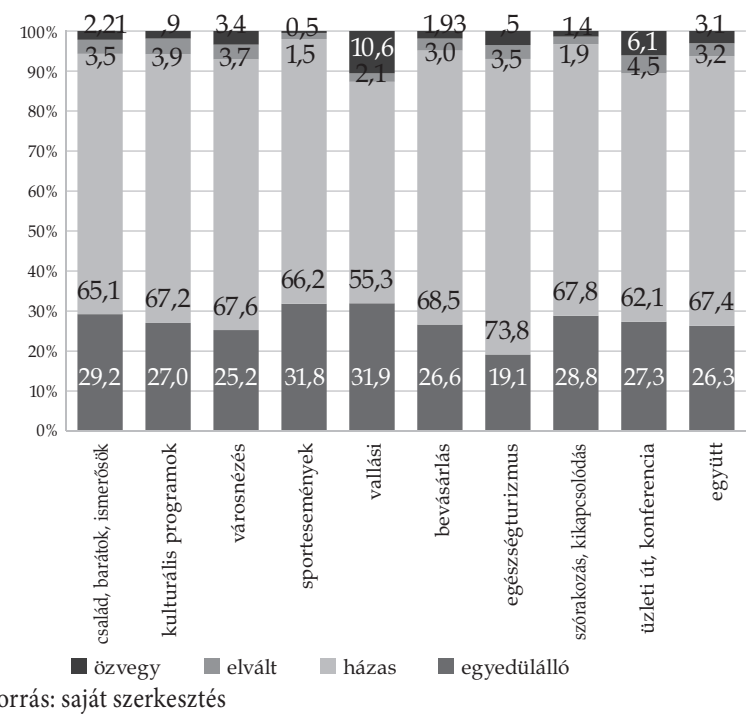

Az elemzés alapján az látható, hogy illeszkedve a város turisztikai adottságaihoz, az egyedülállók és a családosok is megtalálják a motivációjuknak megfeleló turisztikai kínálatot. A motivációt említơk és nem említők szignifikancia vizsgálatánál az elemzés alapján elmondható, hogy a sport $(0,112)$, a vallási célú utazások $(0,114)$, a szórakozás $(0,126)$ esetén találunk szignifikáns eltérést kisebb-nagyobb mértékben. A vizsgálat alapján megállapítható, hogy a családi állapot nem befolyásolja nagymértékben a célok kiválasztását.

6. ábra

Iskolai végzettség szerinti megoszlás az egyes motivációk esetén (\%)

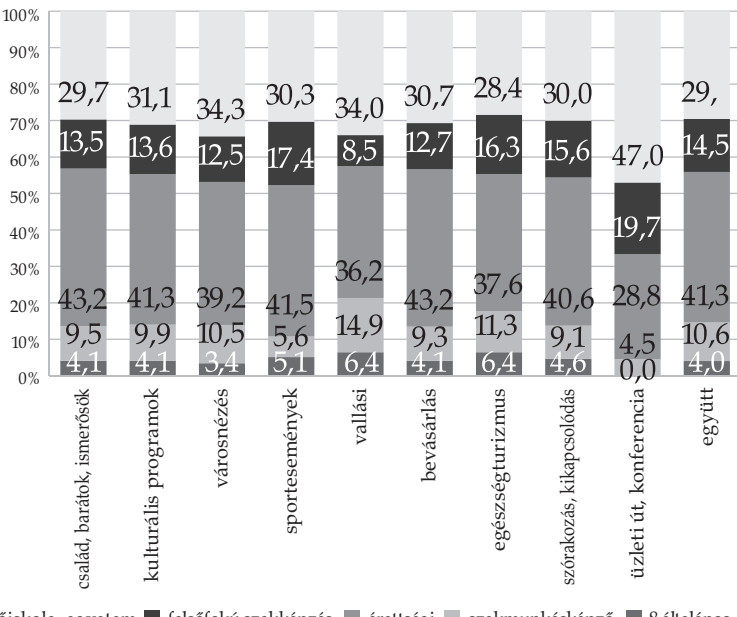

Forrás: saját szerkesztés 
A 6. ábra az iskolai végzettség, mint szocio-demográfiai változó hatásainak elemzését mutatja be. Az ábrán jól látható, hogy az üzleti turizmusban való részvételt jelentôsen befolyásolja az iskolai végzettség. A motivációt legnagyobb arányban a felsőfokú végzettséggel rendelkezôk jelölték be.

Szignifikáns eltérés mutatkozott az említők és a nem említők között a városnézés $(0,107)$, és az üzleti út $(0,139)$ esetén. Zárójelben a kontingencia-együttható nagysága látható, amely a kapcsolat erősségét mutatja.

Az előző eredményeket összesítve, a 3. táblázatban együtt láthatjuk az összefüggéseket. A motivációkat a szocio-demográfiai változók segítségével vizsgálva látszik, hogy viszonylag sok a szignifikáns kapcsolat; főként az életkor tekinthető olyan tényezőnek, amely jelentôsen befolyásolja adott célok választását. A mátrixban szövegesen szerepel, hogy hol vannak kapcsolatok és azok milyenek (négyféle lehetőség: nincs kapcsolat; VAN kapcsolat, de nem lineáris, vagy a linearitás nem értelmezhető; LINEÁRIS, (-) negatív kapcsolat; LINEÁRIS, $(+)$ pozitív kapcsolat).

A 3. táblázatból jól látszik az, hogy a látogatás vagyis maga az utazás - viszonylag erősen kötődik a háttérhez és a társadalmi-demográfiai jellemzőkhöz. Az üzleti utazások elsôsorban a magasabb végzettségú célcsoportra jellemzőek, míg a szabadidős turisztikai keresletnél ez a jellemző nem tekinthető befolyásoló tényezőnek. A kor, mint demográfiai tényező erősen befolyásolja az utazási motivációkat, ami elsősorban a VFR turizmusban, a szórakozás, kikapcsolódás és bevásárló turizmus esetén mutat erős összefüggést, illetve a sportesemények látogatása esetén lineáris, pozitív irányú kapcsolatot fedezhetünk fel.

\subsection{A MÉLYINTERJÚK EREDMÉNYEINEK ÖSSZEFOGLALÁSA}

A kérdőíves kutatás eredményeit kiegészítve 10 mélyinterjú készítésére is sor került. A mélyinterjúk alanyaiként olyan szakembereket választottunk, akik Győr város turizmusában valamilyen módon részt vesznek. Így a kínálati oldalról szállodavezetőkkel, önkormányzati referenssel és a Tourinform iroda vezetőjével készült mélyinterjú.

A turisztikai szakemberek kiemelték, hogy rengeteg átutazó turista megy keresztül a városon, ezért fontos volna őket megállítani és arra sarkallni, hogy vendégéjszakát töltsenek el, programokon vegyenek részt, szolgáltatásokat vegyenek igénybe. Szükséges lenne az üzleti turistákat kimozdítani komfortzónájukból és megismertetni velük Gyôr értékeit, ami által valamelyest szabadidôs turistákká tudnának válni. A cél az, hogy üzleti útjaik során olyannyira nyerje el tetszésüket a város, hogy legközelebb családosan térjenek vissza, kihasználva az ott lévő lehetôségeket.

Újdonságként megemlítették a Győr Kártyát, amely egy olyan komplex turisztikai termék, mely egyfajta kedvezménygyưjtő kártyaként múködik. Célja, hogy a lehető legtöbb költésre ösztönözzék a turistákat.

\section{A Győrben már járt vendégek motivációinak összefüggései}

3. táblázat

\begin{tabular}{|c|c|c|c|c|}
\hline & $\mathrm{Nem}$ & Kor & Családi állapot & Iskolai végzettség \\
\hline család, barátok, ismerősök & nincs kapcsolat & $\begin{array}{l}\text { LINEÁRIS, } \\
\text { (-) kapcsolat }\end{array}$ & nincs kapcsolat & nincs kapcsolat \\
\hline kulturális programok & $\begin{array}{l}\text { VAN kapcsolat, } \\
\text { de nem lineáris }\end{array}$ & nincs kapcsolat & nincs kapcsolat & nincs kapcsolat \\
\hline városnézés & nincs kapcsolat & nincs kapcsolat & nincs kapcsolat & $\begin{array}{l}\text { VAN kapcsolat, } \\
\text { de nem lineáris }\end{array}$ \\
\hline sportesemények & $\begin{array}{l}\text { VAN kapcsolat, } \\
\text { de nem lineáris }\end{array}$ & $\begin{array}{l}\text { LINEÁRIS, } \\
\text { (+) kapcsolat }\end{array}$ & $\begin{array}{l}\text { VAN kapcsolat, } \\
\text { de nem lineáris }\end{array}$ & nincs kapcsolat \\
\hline vallási & nincs kapcsolat & nincs kapcsolat & $\begin{array}{l}\text { VAN kapcsolat, } \\
\text { de nem lineáris }\end{array}$ & nincs kapcsolat \\
\hline bevásárlás & nincs kapcsolat & $\begin{array}{l}\text { LINEÁRIS, } \\
\text { (-) kapcsolat }\end{array}$ & nincs kapcsolat & nincs kapcsolat \\
\hline egészségturizmus & nincs kapcsolat & nincs kapcsolat & nincs kapcsolat & nincs kapcsolat \\
\hline szórakozás, kikapcsolódás & $\begin{array}{l}\text { VAN kapcsolat, } \\
\text { de nem lineáris }\end{array}$ & $\begin{array}{l}\text { LINEÁRIS, } \\
\text { (-) kapcsolat }\end{array}$ & $\begin{array}{l}\text { VAN kapcsolat, } \\
\text { de nem lineáris }\end{array}$ & nincs kapcsolat \\
\hline üzleti út, konferencia & $\begin{array}{l}\text { VAN kapcsolat, } \\
\text { de nem lineáris }\end{array}$ & nincs kapcsolat & nincs kapcsolat & $\begin{array}{l}\text { LINEÁRIS, } \\
\text { (+) kapcsolat }\end{array}$ \\
\hline
\end{tabular}

Forrás: saját szerkesztés 
Lektorált tanulmányok

A turisztikai szakemberek, még a szállodások is megemlítették, hogy nagyon hiányzik a város szálláshely kínálatából egy gyógy- vagy wellness szálloda. Több turistát vonzana, így növelni lehetne az átlagos tartózkodási idót is. Fontos azonban kiemelni, hogy hosszú idő szükséges ahhoz, hogy Győr a wellnessre és a gyógyvízre alapozhasson. Egy ilyen szálloda megépítése jelentős költségekkel jár, és a későbbiekben a fenntartása is költséges.

A programkínálatról elmondták, hogy Győr városában sok program van, ami megfelelő a városnak. A nagyobb programok, például a Győrkőcfesztivál és az Adventi vásár, sok turistát vonzanak, amit a szállodák foglalási szinten is megéreznek. Ezek alapján a szakértők szerint nem a fesztiválokra kellene helyezni a hangsúlyt, hanem inkább egy olyan szolgáltatást létrehozni, ami egész évben folyamatosan nyitva áll a turisták előtt, és akár egész napos elfoglaltságot tud nyújtani. Kedvező hatású lehetne valamilyen témapark, amely növelhetné a vonzerőt, hiszen felnőttnek, gyereknek egyaránt szórakozást nyújt. Fontos kiemelni, hogy nem az ötletek hiányoznak ebben az irányban, sokkal inkább a forrás hiánya miatt nem valósulhatnak meg az ötletek.

A szakértői interjúk sok tekintetben alátámasztották és megerősítették a kérdôíves kutatás eredményeit. A turisztikai szakértôk egy része külön kihangsúlyozta, hogy olyan városmarketing kellene, amely megkülönböztetné Győrt a többi várostól.

\section{Következtetések}

A kutatás alapján megállapítható, hogy az üzleti turizmus vezetó szerepe mellett egyre nagyobb teret nyerhet a szabadidós turizmus, különbözó megjelenési formákban. A motivációk választása és a szocio-demográfiai változók összefüggésének vizsgálata megmutatta, hogy elsősorban az életkor az a tényezô, amely jelentósen befolyásolja a turisták motivációját.

Vizsgálatunk alapján azt is láthatjuk, hogy Győr turisztikai kínálata lehetôvé teszi a szabadidôs turizmus arányának növelését a városban. Elsősorban a kulturális turizmus és a hozzá kapcsolódó programok (például városnézés) területén látható fejlesztési potenciál, ugyanakkor a turisztikai szolgáltatások kínálati oldalát is érdemes fejleszteni a vendégéjszakák számának növelése érdekében.

További lehetôségeket találtunk az egészségturizmus és a sportturizmus területén, de ezeken a területeken a kínálati elemek további fejlesztése szükséges. Egy új gyógy- vagy wellness szálloda valóban új vendégkört hozhatna a városba na- gyobb földrajzi távolságból is, hosszabb tartózkodási időre, amely a forgalomból származó és az adóbevételek növekedésére is kedvezóen hatna.

A következó évekre vonatkozóan szerepel az Önkormányzat tervei között a barokk belváros rehabilitációja, sportlétesítmények építése, kulturális események és intézmények támogatása, wellness hotel beruházás támogatása, a város promotálása turisztikai szempontból és az idegenforgalmi adó visszaforgatása.

Összefoglalva elmondható, hogy Győr egy folyamatosan fejlődó innovatív város, amely ugyan átalakuló ipari jelleggel bír, de a turizmus hangsúlyosan van jelen a gazdaságban. Az üzleti turizmus egyre inkább kiegészül a szabadidős turizmussal, amelynek érdekében sokat tesz a város, azonban még számos további fejlesztés szükséges a nagyobb siker érdekében.

\section{Felhasznált irodalom}

ALBERT TÓTH A. (2009): A kulturális fesztiválok, programok szerepe és jelentősége a szállodaiparban. XII. Apáczai-napok Nemzetközi Tudományos Konferencia, Nyugat-magyarországi Egyetem, Apáczai Csere János Kar, Gyôr. Tanulmánykötet. pp. 486-493.

ALBERT TÓTH A. (2016): Győr-Moson-Sopron megye szállodaipara. XIX. Apáczai-napok Nemzetközi Tudományos Konferencia, Nyugat-magyarországi Egyetem, Apáczai Csere János Kar, Győr. Tanulmánykötet. pp. 579-589.

ASHWORTH, G. J. (1988): Marketing the historic city for tourism. In: Goodall, B. - Ashworth, G. J. (eds.): Marketing in the tourism industry. Croom Heln, Beckenham.

ASHWORTH, G. J. - VOGD, H. (1990): Selling the City: Marketing Approaches in Public Sector Urban Planning. Belhaven Press, London.

BUDAI és BARTA TANÁCSADÓ KFT. (2007): Győr és térsége turizmusfejlesztési stratégiája.

CIBINSKIENEA, A. - SNIESKIENEB, G. (2015): Evaluation of city tourism competitiveness. Procedia - Social and Behavioral Sciences. 213. pp. 105-110.

GYŐR-MOSON-SOPRON MEGYEI ÖNKORMÁNYZAT (2016): Győrr-Moson-Sopron megye kincsei.

HANCZ G. (2017): A hazai vidéki városok előtt Győr - Az Európai Bizottság a kontinens 168 kulturális és kreatív városát rangsorolta. Kisalföld, K2 melléklet. 2017.10.21. pp. 2-3.

HAPP, É. - ÉKES, SZ. (2014): Hungary. In: Tučková, Z. (ed): The Meaning of Tourism and Tourism Services in the V4 Countries. Georg, Žilina. pp. 64-76. 
JAKAB, P. - HAPP, É. (2017): Impact Assessment between the City and the Company Reputation. Economics and Sociology. 10(1). pp. 11-25.

KSH (Központi Statisztikai Hivatal) (2008-2016) Turizmus statisztikák. Tájékoztatási adatbázis. www.ksh.hu

LAW, M. C. (1993): Urban Tourism. Attracting Visitors to Large Cities. Mansell Publishing Ltd. London, New York.

MICHALKÓ G. (1999): A városi turizmus elmélete és gyakorlata. MTA, Földrajztudományi Kutató Intézet, Budapest.

MIKULIC, J. - MILICEVIC, K. - KRESIC, D. (2016): The relationship between brand strength and tourism intensity: empirical evidence from the EU capital cities. International Journal of Culture, Tourism and Hospitality Research. 10(1). pp. 14-23.

MTÜ (Magyar Turisztikai Ügynökség) (2017): Magyarország leglátogatottabb települései 2016-ban, a kereskedelmi szálláshelyeken regisztrált vendégéjszakák száma szerint. https://mtu.gov.hu/documents/prod/legnepszerubb_telepulesek_2016_ vegleges.pdf, Letöltve: 2017. október 22.

PASKALEVA-SHAPIRA, K. A. (2007): New Paradigms in City Tourism Management: Redefining Destination Promotion. Journal of Travel Research. 46. pp. 108-114.

RECHNITZER J. (2016): A területi tóke a városfejlódésben. A Győr-kód. Dialóg Campus Kiadó, Budapest-Pécs.
RICHARDS, G. (2011): Creativity and tourism: The state of the art. Annals of Tourism Research. 38(4). pp. 1225-1253.

RICHARDS, G. (2014): Creativity and tourism in the city. Current Issues in Tourism. 17(2). pp. 119-144.

RICHARDS, G. - WILSON, J. (2004): The impact of cultural events on city image: Rotterdam cultural capital of Europe 2001. Urban Studies. 41(10). pp. 1931-1951.

SPIROU, C. (2011): Urban Tourism and Urban Change. Cities in a Global Economy. Routledge, New York.

SUDÁR Á. (2017): Győzelemre szerződtek. Európa Kulturális Fóvárosa - Gyór nem egyedül, hanem partnerekkel pályázik 2023-ra. Kisalföld. 2017.12.13. pp.1-3.

TOKARCHUK, O. - GABRIELE, R. - MAURER, O. (2016): Development of city tourism and well-being of urban residents: A case of German Magic Cities. Tourism Economics. 23(2). pp. 343-359.

TÓTHNÉ KARDOS K. (2015): Győr ma már nem "csupán" iparváros. Polgári Szemle. 11(4-6) pp. 582-592.

VALLS, J. F. - SUREDA, J. - VALLS-TUNON, G. (2014): Attractiveness Analysis of European Tourist Cities. Journal of Travel \& Tourism Marketing. 31(2). pp. 178-194. 